\title{
An Inordinate Fondness? The Number, Distributions, and Origins of Diatom Species
}

\author{
David G. Mann ${ }^{a}$ \& Pieter Vanormelingen ${ }^{b}$ \\ a Royal Botanic Garden Edinburgh, 20A Inverleith Row, Edinburgh, EH3 5LR, United Kingdom \\ b Laboratory of Protistology and Aquatic Ecology, Ghent University, Krijgslaan 281 - S8, 9000, Gent, Belgium
}

\begin{abstract}
Keywords
Biodiversity; biogeography; cryptic species; diatoms; endemism; pseudocryptic species; speciation; species concept; systematics; taxonomy.

\section{Correspondence}

D.G. Mann, Royal Botanic Garden Edinburgh, 20A Inverleith Row, Edinburgh EH3 5LR, United Kingdom.

Telephone number: +44 (0) 1315527171 ; FAX number: +44 (0) 131248 2901;

e-mail: d.mann@rbge.org.uk
\end{abstract}

Received: 1 March 2013; accepted March 5, 2013.

doi:10.1111/jeu.12047

\begin{abstract}
The number of extant species of diatoms is estimated here to be at least 30,000 and probably ca. 100,000 , by extrapolation from an eclectic sample of genera and species complexes. Available data, although few, indicate that the pseudocryptic species being discovered in many genera are not functionally equivalent. Molecular sequence data show that some diatom species are ubiquitously dispersed. A good case can be made that at least some diatom species and even a few genera are endemics, but many such claims are still weak. The combination of very large species numbers and relatively rapid dispersal in diatoms is inconsistent with some versions of the "ubiquity hypothesis" of protist biogeography, and appears paradoxical. However, population genetic data indicate geographical structure in all the (few) marine and freshwater species that have been examined in detail, sometimes over distances of a few tens of kilometres. The mode of speciation may often be parapatric, in the context of a constantly shifting mosaic of temporarily isolated (meta) populations, but if our "intermediate dispersal hypothesis" is true (that long-distance dispersal is rare, but not extremely rare), allopatric speciation could also be maximized.
\end{abstract}

On being asked what one could conclude as to the nature of the Creator from a study of his creation, Haldane is said to have answered, "An inordinate fondness for beetles"

Hutchinson (1959)

\section{BEETLES OR PANDAS?}

In 1996, one of us published a guess about the number of diatom species on earth: the number was 200,000. This estimate (Mann and Droop 1996, p. 28) was composed of two parts: (1) a multiplier of 10 applied to the ca. $10^{4}$ species already described, because the taxonomy used was too coarse-grained, combining different species under the same name and (2) a further doubling to take account of understudied habitats. The 200,000 guess has been widely cited but rarely assessed critically and surprisingly few counter-estimates have been made, one of these being in a recent paper by Guiry (2012). Guiry comments that some diatomists have sought to apply a version of the biological species concept and this "may result in huge numbers of microspecies of dubious utility." Preferring to reject species that cannot be identified without "extensive breeding programs or gene sequencing," Guiry goes on to suggest reliance, at least for now, on morphological characters. He gives a "conservative figure of
12,000 described species of diatoms, with a further 8,000 to be discovered". In other words, according to Guiry, we already know more than half of the diatom species that exist (although that, of course, still leaves a lot of work to be done) - far from the 20-fold multiplier suggested by Mann and Droop. So, what is the truth about diatom diversity? Are they the beetles of the protist world, or a playground for voyeurs and stamp collectors, or a bit of both?

Mann and Droop made their estimate by extrapolation from a small number of cases in which detailed studies of existing species had led to the recognition of hitherto unsuspected or misunderstood diversity. Some of the studies referred to by Mann and Droop used mating compatibility as a guide to species limits; others used morphometrics (e.g. Droop 1994; Theriot 1992). Furthermore, at that time, there had been scarcely any molecular studies of speciation in diatoms and, since the mating studies done until then had involved natural populations not cultures, it was a prerequisite that the "biological" species that Mann and Droop appealed to as part of the justification for a 10-fold inflation of existing species numbers were distinguishable morphologically: they were at worst "pseudocryptic" sensu Mann and Evans (2007). Since 1996, however, sequence data have been employed by several laboratories to investigate species-level variation and this has made it possible for the first time to explore 
whether truly "cryptic" variation exists. It does (e.g. Quijano-Scheggia et al. 2009).

How can one estimate how many diatom species are not yet known? One possibility is to look at the rate of species description and see whether it is decreasing, giving evidence of an approach to saturation. However, this depends on whether taxonomic effort is constant and consistent, and it certainly is not: the last four decades have witnessed significant changes, up and down, in the degree of morphological difference regarded as necessary for species-level separation (Mann 1999, p. 444-447; or compare the treatment of Eunotia by Lange-Bertalot et al. 2011 with that of Krammer and Lange-Bertalot 19861991). Another possibility would be to use an environmental DNA approach to reveal how many diatom molecular operational taxonomic units are present at locations carefully selected to represent the whole spectrum of environments that diatoms inhabit, and to compare the number obtained with the number of named species identifiable (morphologically or using molecular data) in the same material. This has not been done. So, we will adopt the same eclectic approach as Mann and Droop (1996), examining the histories of particular, well-studied examples to see what they suggest concerning the multiplier that should be applied to the number of species already known, in order to estimate the total number of species that actually exist. In Appendix S1, we summarize several case histories, each chosen on the basis that the genus or group is well defined and has been worked on actively and with an internally consistent taxonomic approach since 1978. As "already known" is a constantly shifting concept, VanLandingham's (1967-1979) catalogue will be taken as a starting point, and we will accept the estimates made by various authors (e.g. Werner 1977, p. 2, 11, 384) that at that time, the total number of acceptable, described extant species was $10^{4}$. On this basis, the multiplier implicit in Guiry's (2012) estimates would be ca. $\times 2$, since his starting point (of $12,000 \mathrm{spp}$ ) already takes into account many additions made since VanLandingham's work.

In the few genera where molecular data have been used extensively for taxonomic revision - Pseudo-nitzschia and Skeletonema - the multipliers are at least $\times 3$ and $\times 4.5$ respectively. These two genera have been subject to particularly intense sampling effort and, although it is already clear that more species remain to be described, the current number of species in each genus is probably only a little less than the final total. The multipliers for these two genera since VanLandingham can therefore serve as the lower limit for the diatoms as a whole, giving an estimate of at least $3 \times 10^{4}$ extant species. However, these two genera belong to the best understood and most often sampled communities in which diatoms are abundant, the phytoplankton: by the middle of the 20th century, the species-level taxonomy of planktonic diatoms had already been tried and tested by several generations of oceanographers and ecologists. Not surprisingly, therefore, several of the examples analysed in Appendix S1 (notably Brachysira, the Sellaphora bacillum group, and the
Sellaphora pupula group), involving benthic diatoms, yield much higher estimates of the multiplier, of $\times 8$ or more. This is so even though the estimates are based solely upon morphological criteria and so cannot take account of cryptic species, which are present in both Pseudo-nitzschia and Skeletonema.

The example of Sellaphora auldreekie (included in the $S$. pupula group referred above and discussed in Appendix S1) illustrates the possible impact of molecular data in revealing cryptic speciation. Sellaphora auldreekie was originally included within $S$. pupula but then separated from it as a result of a morphological, morphometric, and mating study of Sellaphora species in some Scottish ponds (Mann et al. 2004). Molecular studies by Evans et al. $(2007,2008)$ confirmed the separation of $S$. auldreekie from other Sellaphora species. However, a subsequent study of a few lakes in Europe and Australia, using a polyphasic approach including molecular data (P. Vanormelingen et al., in press), has shown that auldreekie-like diatoms comprise a complex of at least six closely related species (see Appendix S1). Other examples in which sequence data have suggested that several species are present within a complex that is difficult or impossible to dissect using traditional LM- and SEM-based methods include Cylindrotheca closterium (Vanormelingen et al. 2013), Eunotia bilunaris (Vanormelingen et al. 2007), Frustulia rhomboides (Veselá et al. 2012), Navicula cryptocephala (Poulícková et al. 2010), Navicula phyllepta (Vanelslander et al. 2009), Nitzschia palea (Trobajo et al. 2009, 2010), Nitzschia fonticola (Trobajo et al. 2006), Hantzschia amphioxys, and Pinnularia borealis (Souffreau et al. 2013b). In several of these (S. auldreekie, E. bilunaris, N. palea, N. cryptocephala), lineages revealed by molecular phylogenetic analysis have been shown to be separated by barriers to interbreeding. Although species-level molecular studies of benthic diatoms are still not numerous, no example is known to us where a species recognized by VanLandingham has been sampled extensively and found to be homogeneous. As each species complex is sampled more intensively, more and more discrete entities, fulfilling the concept of species as separately evolving metapopulation lineages (De Queiroz 2007; Mann 2010), emerge. For example, E. bilunaris was initially revealed to contain three lineages (at least two of which retain some ability to pair, but with strong prezygotic reproductive isolation and hybrid sterility (Vanormelingen et al. 2008b)), but the E. bilunarisflexuosa group is now known to contain 15 lineages ( $P$. Vanormelingen, unpubl. data), tending to support the recent splitting of the group, based solely on morphology, by Lange-Bertalot et al. (2011).

Hence, although there is clear evidence of phenotypic plasticity in the morphological characters used to separate diatom species (e.g. Shirokawa et al. 2012; Trobajo et al. 2011), which will probably reduce the number of previously described species to some degree through synonymy, there seems no doubt that even the best morphology-based classifications will considerably underestimate species diversity. Therefore, multipliers based purely on morphology, such as those discussed in Appendix S1, which range from $\times 2.1$ to $\times 14$, must be regarded as minimal. 
Finally, as noted previously by Mann and Droop (1996), some parts of the biosphere where diatoms are abundant are known very poorly indeed. Few studies have been made of freshwater or marine epipsammic diatoms. Most freshwaters in the tropics have yet to be studied using modern microscopy and many have not been sampled at all. The extent to which extra diversity can be expected can be gauged from Hustedt (1937-1939, 1942) classic studies of Indo-Pacific freshwaters, never bettered within the tropical zone, in which many new species were recorded. In the succeeding $70 \mathrm{yr}$, few if any other parts of the tropics have received such close attention. The task of properly documenting tropical freshwater diversity fades into insignificance, however, compared with the challenges of the marine littoral and sublittoral, not only in the tropical zone but also in temperate and polar regions. There is almost nothing to start from: descriptions of taxa are scattered through the literature, often in publications that are difficult to obtain, and no critical floras comparable to those for freshwaters (i.e. analogous to Krammer and Lange-Bertalot 1986-1991) have been published in the last $100 \mathrm{yr}$. A survey of almost any tidal beach quickly reveals examples of pseudocryptic diversity (see the examples of Hantzschia and Diploneis in Appendix S1) and many diatoms that cannot be identified. Knowledge of the subtidal benthos is worse, because of the difficulty of sampling. Examination of subtidal sediments around Scottish coasts (e.g. Droop 1998; Gregory 1857; Park 1992; collections by H.M. Jones et al. in the herbarium, Royal Botanic Garden Edinburgh) shows a rich and unfamiliar flora, containing species (e.g. Lyrella praetexta, Lyrella nebulosa, members of Nitzschia sect. Insignes) that do not extend out from the subtidal into more easily sampled intertidal regions.

Overall, then, we conclude that Guiry's estimate of a total of ca. 20,000 extant species is too low. Estimates derived using genera from well-sampled diatom communities (Pseudo-nitzschia, Skeletonema) indicate that there really cannot be less than 30,000 species. Some relatively well-studied benthic genera (Sellaphora, Brachysira) indicate a much higher figure - perhaps 80,000 - even without taking into account cryptic species. The largely unknown marine littoral could add many more. The total of 200,000 extant diatoms estimated by Mann and Droop (1996) remains possible, but it is towards the upper end of the range suggested by the data included here; 100,000 seems more likely, which still makes the diatoms the beetles of the algal world.

\section{FUSSY PATRIOTIC BEETLES OR TRAMPS?}

We will now consider another part of the comment by Guiry (2012) mentioned above, that the huge numbers of undescribed diatom species that we argue exist may be "microspecies of dubious utility", which presumably, therefore, can be safely ignored. "Microspecies" is a word often used to refer to each of the many slightly different, independently evolving lineages of an agamic complex (e.g. Coyne and Orr 2004), in which apomixis often arises in association with hybridization and polyploidy (Stebbins
1950). There is evidence for extreme (intraindividual) selfing and apomixis in some diatoms (Chepurnov et al. 2004; Mann et al. 2013), which could potentially create myriad "microspecies" that it would be impractical and undesirable to recognize formally. It is possible that some taxonomically awkward variation in genera like Nitzschia may be brought about by such reduced or lost sexuality (e.g. Trobajo et al. 2006). However, it appears that loss or reduction of sexuality has occurred many times independently (e.g. Mann et al. 2013), and as yet there is little evidence of extensive, long-term diversification of auto- or apomicts into arrays of "microspecies". One possible example is "Nitzschia inconspicua", which appears to comprise a paraphyletic group of paedogamous lineages that differ subtly in size and striation density (and also exhibit diverse responses to salinity). The diversification of $N$. inconspicua may have begun several million years ago, since the basal divergences appear to predate the origin of another species in the same clade, Nitzschia amphibia (L. Rovira et al., in preparation), which is known from the Miocene. Another possible example is the E. bilunaris "labile" lineage, which consists of a confusing amalgam of heterothallic and apomictic strains with subtly different morphologies (Vanormelingen et al. 2008b, unpubl. data). In general, however, (pseudo)cryptic diatom lineages seem to be fully sexual obligate or facultative outbreeders, and the few cases with fossil-based time-calibration indicate that lineage divergence took place in the order of $100,000 \mathrm{~s}$ to (many) millions of years ago (Casteleyn et al. 2010; Souffreau et al. 2013b). Currently, therefore, there is no reason to regard the new species being revealed by careful morphological, mating or molecular studies as "microspecies": use of this word is pejorative. However, diatom species are nevertheless challenging to discover and identify, and it is reasonable to ask whether this activity is worthwhile, even though DNA barcoding approaches are being developed (reviewed by Mann et al. 2010) and offer the possibility of more certain and increasingly inexpensive identification.

Some people might argue that, if a set of morphologically similar species share similar ecology, distinguishing individual species within the set may be a luxury we can do without (which is to devalue diatom and other protist species and their contributions to the Earth system, relative to species of macrobiota, e.g. bonobos, pandas or the St Helena ebony). This is obviously not the case for fields such as community and macroecology, speciation research, (conservation) biogeography, and population genetics, all of which rely heavily for at least some fundamental aspects on a species taxonomy reflecting the actual species limits and diversity present. On the other hand, environmental reconstruction using diatoms as indicators would only benefit from distinguishing these "new" species if they differ significantly in their ecology. So, do they? Not surprisingly, given how difficult it is, using morphology alone, to reliably identify many of the new species being described (including many of those in the genera considered in Appendix S1), there are few relevant data. However, the information available suggests 
that the new species do often have different ecological and physiological characteristics. This has been shown in relation to overall nutrient status in Sellaphora (Poulíčková et al. 2008); salinity responses in the $N$. phyllepta complex (Créach et al. 2006; Vanelslander et al. 2009) and in Skeletonema (Balzano et al. 2011), where there are also differences between species in their responses to temperature and light (Kaeriyama et al. 2011); and responses to temperature in $H$. amphioxys sensu lato and $P$. borealis (Souffreau et al. 2013b), which are both terrestrial diatoms, and in the marine planktonic Chaetoceros socialis (Degerlund et al. 2012; Huseby et al. 2012). In these cases, the component species of each species complex are not equivalent and being able to separate them holds the promise of improved diatom-based environmental reconstructions.

Do closely related species replace each other in comparable niches in different regions or continents, or are they all everywhere? It used to be thought that many diatom species were widely distributed, occurring wherever their physical and chemical requirements were met. For example, the freshwater diatom flora of Krammer and Lange-Bertalot (1986-1991) annotates many species as cosmopolitan. The "ubiquity" hypothesis (Finlay and Clarke 1999; Finlay et al. 2002) provided an explanation of the supposed wide distributions of protists as the inevitable consequence of the enormous sizes of microbial populations, which was suggested to drive rapid worldwide dispersal despite the low probability that any given cell will be transported elsewhere and successfully establish. Finlay et al. (2002) therefore suggested that claims of diatoms that appeared to be restricted to a particular lake or region may be the result of taxonomic ignorance, inappropriate sampling, the uniqueness of the habitat, or the difficulty of detecting a diatom species when rare. There is a stark contrast between this assessment and recent diatom literature, which contains many claims of endemism. For example, accounts of the diatoms of New Caledonia (Moser et al. 1998), Lakes Prespa and Ohrid in SE Europe (Levkov et al. 2007), or Lake Baikal (Kulikovskiy et al. 2012) contain many new species that are suggested to be found only there. Earlier, Hustedt (1942) made similar claims for species discovered in Indonesia and the Philippines. He acknowledged that some of them might subsequently be found to have wider distributions within the tropics, but predicted that a significant proportion would be confirmed to be restricted to an island, or even to a single lake. Indeed, among the six or more local endemics Hustedt listed for each of Lakes Mahalona, Matano, Towuti, and Wawotobi on Sulawesi, some have never been reliably identified elsewhere, including Nitzschia invisitata (recently reviewed by Trobajo et al. 2013).

Such examples can be criticized, fairly, on the basis that the ecological niches of the species have not been characterized, so that we have not found them elsewhere simply because we do not know where and when to look. After almost $40 \mathrm{yr}$ of sampling, the senior author has yet to find Nitzschia scalaris, although the species has been known in the UK since the 1850s (Smith 1853). Furthermore, use of literature records to establish geo- graphical ranges is risky because, for morphologically defined species, different people not infrequently give the same name to different species, and different names to the same species. We therefore agree with Finlay et al. that many claims about diatom distributions and endemism must be treated with scepticism. A nice illustration is the study of Psammothidium abundans by Van de Vijver et al. (2008), which showed that a diatom that had previously appeared to be a good example of a "subantarctic endemic" is actually abundant in European rivers. Nevertheless, as discussed by Vanormelingen et al. (2008a), there are some convincing examples of diatoms with restricted distributions. One is Eunophora, present in well-characterized oligo- and dystrophic waters in Australasia but never yet found in apparently equivalent habitats in the northern hemisphere despite intense sampling over many years.

So far, molecular data have not revealed any clear examples of narrow endemism, which is not surprising since the appropriate molecular methods - such as largescale screening of environmental samples via next-generation sequencing using markers with species-level resolution - have scarcely ever been applied to diatom communities. Using molecular data to confirm ubiquity is more straightforward and there have been several demonstrations of widely distributed diatom species, including Pseudo-nitzschia (Trainer et al. 2012) and Skeletonema species (Kooistra et al. 2008), but also freshwater benthic diatoms such as Sellaphora capitata, Sellaphora bisexualis and S. auldreekie (which are found as far apart as the UK and Australia: Evans and Mann 2009; Mann et al. 2009; P. Vanormelingen, unpubl. data), and some haplotypes of N. palea (found in Japan and Spain: Trobajo et al. 2009, 2010). The freshwater examples lack desiccation-resistant vegetative cells or dormant stages (Souffreau et al. 2010, 2013a, unpubl. data), but seem nevertheless to have dispersed effectively over large distances, consistent with Finlay et al.'s (2002) suggestion of ubiquitous dispersal driven by the huge size of source populations. While the proportion of widespread diatom species remains unclear at present, the idea of relatively easy long-distance dispersal is also supported by data on colonization of newly created habitats, e.g. reservoirs and volcanic islands (Atkinson 1988; Behre and Schwabe 1970), and by the apparent lack of major lags in the development of a rich diatom flora in newly deglaciated regions. At the continental scale and in isolated regions, on the other hand, there is some evidence of dispersal limitation of diatoms, from statistical analyses of floras at the generic level (Vyverman et al. 2007).

Summary? Diatoms are fussy and sometimes patriotic tramps, but claims of endemism are made too lightly.

\section{HOW HAVE SO MANY BEETLES EVOLVED?}

Finlay et al. (2004) suggested that, as a result of rapid and ubiquitous dispersal in protists, the rate of allopatric speciation would be low and consequently also the proportion of endemics and the global number of 
morphospecies. Paradoxically, diatoms do seem to disperse rapidly, compared to angiosperms or terrestrial vertebrates, yet they contain many morphospecies and some (perhaps many) endemics. How then do diatom species arise? Are their populations essentially panmictic at a regional (up to $\sim 10^{4} \mathrm{~km}$ ) scale? Must their speciation be mostly sympatric (ecological) and consequently an interesting exception to the traditional view that allopatric speciation is the norm?

Population genetics and studies of reproductive biology are beginning to supply insights into diatom speciation. Microsatellite data for widespread species of sexual, potentially interbreeding organisms, such as Pseudo-nitzschia pungens (marine planktonic), and $S$. capitata and E. bilunaris (both freshwater benthic), show that their populations are geographically structured (respectively, Casteleyn et al. 2010; Evans et al. 2009; P. Vanormelingen, in press). Geographical structure is also apparent in sequence data for other Pseudo-nitzschia species (e.g. Moschandreou et al. 2012). The spatial scales of differentiation vary. In E. bilunaris and S. capitata (in both cases, unpublished new results of $P$. Vanormelingen), a few tens of kilometres of separation have permitted high genetic divergence, whereas $P$. pungens is panmictic over a large part of the North Sea (Casteleyn et al. 2009; Evans et al. 2005).

It seems, therefore, that although long-distance dispersal seems in many cases to be effective enough for species to establish across large geographic areas, gene flow is not frequent enough over the short term to prevent populations from diverging. Perhaps, then, diatom speciation is often parapatric, each species consisting of a constantly shifting mosaic of temporarily separate, differentiating (meta)populations (over say $10^{3}-10^{4} \mathrm{yr}$ ), some of which become fully reproductively isolated during their separation while others later fuse back into the larger commiscuum. This model focuses attention onto the mechanisms by which intrinsic or extrinsic reproductive isolation is achieved in diatoms: perhaps the processes of attraction and recognition between gametes (sperm and eggs in centric diatoms; spermatia and sessile gametes in araphid pennates) or sexualized vegetative cells (in raphid diatoms) are so mutable that, by chance, some of the populations temporarily isolated by distance also become isolated reproductively before they are linked again with their congeners. However, our "intermediate dispersal hypothesis" could also promote allopatric speciation in geographically separated regions with suitable habitat, because there will be a relatively high chance of both: (1) successful colonization and (2) divergence in isolation.

\section{ACKNOWLEDGMENTS}

We are very grateful to Zlatko Levkov for very kindly answering questions about his work and sending us information about his forthcoming treatment of Luticola; and Caroline Souffreau, Rosa Trobajo, and Laia Rovira for information about work in progress and discussion.

\section{LITERATURE CITED}

Atkinson, K. M. 1988. The initial development of net phytoplankton in Cow Green reservoir (Upper Teesdale), a new impoundment in northern England. In: Round, F. E. (ed.), Algae and the Aquatic Environment. Biopress, Bristol. p. 30-43.

Balzano, S., Sarno, D. \& Kooistra, W. H. C. F. 2011. Effects of salinity on the growth rate and morphology of ten Skeletonema strains. J. Plankton Res., 33:937-945.

Behre, K. \& Schwabe, G. H. 1970. Auf Surtsey/lsland im Sommer 1968 nachgewiesene nicht marine Algen. (Über die natürliche Frühbesiedlung postvulkanischer Substrate oberhalb des Litorals). Schriften Naturw. Ver. Schlesw.-Holst. (Suppl.): 31-100.

Casteleyn, G., Evans, K. M., Backeljau, T., D'hondt, S., Chepurnov, V. A., Sabbe, K. \& Vyverman, W. 2009. Lack of population genetic structuring in the marine planktonic diatom Pseudonitzschia pungens (Bacillariophyceae) in a heterogeneous area in the Southern Bight of the North Sea. Mar. Biol., 156:1149 1158.

Casteleyn, G., Leliaert, F., Backeljau, T., Debeer, A.-E., Kotaki, Y., Rhodes, L., Lundholm, N., Sabbe, K. \& Vyverman, W. 2010. Limits to gene flow in a cosmopolitan marine planktonic diatom. PNAS, 107:12952-12957.

Chepurnov, V. A., Mann, D. G., Sabbe, K. \& Vyverman, W. 2004. Experimental studies on sexual reproduction in diatoms. Int. Rev. Cytol., 237:91-154.

Coyne, J. A. \& Orr, H. A. 2004. Speciation. Sinauer, Sunderland, MA.

Créach, V., Ernst, A., Sabbe, K., Vanelslander, B., Vyverman, W. \& Stal, L. J. 2006. Using quantitative PCR to determine the distribution of a semicryptic benthic diatom, Navicula phyllepta. J. Phycol., 42:1142-1154.

Degerlund, M., Huseby, S., Zingone, A., Sarno, D. \& Landfald, B. 2012. Functional diversity in cryptic species of Chaetoceros socialis Lauder (Bacillariophyceae). J. Plankton Res., 34:416431.

De Queiroz, K. 2007. Species concepts and species delimitation. Syst. Biol., 56:879-886.

Droop, S. J. M. 1994. Morphological variation in Diploneis smithii and D. fusca (Bacillariophyceae). Arch. Protistenk., 144:249 270.

Droop, S. J. M. 1998. Diploneis sejuncta (Bacillariophyta) and some new species from an ancient lineage. Phycologia, 37:340-356.

Evans, K. M. \& Mann, D. G. 2009. A proposed protocol for nomenclaturally effective DNA barcoding of microalgae. Phycologia, 48:70-74.

Evans, K. M., Kuhn, S. F. \& Hayes, P. K. 2005. High levels of genetic diversity and low levels of genetic differentiation in North Sea Pseudo-nitzschia pungens (Bacillariophyceae) populations. J. Phycol., 41:506-514.

Evans, K. M., Wortley, A. H. \& Mann, D. G. 2007. An assessment of potential diatom "barcode" genes (cox1, rbcL, 18S and ITS rDNA) and their effectiveness in determining relationships in Sellaphora (Bacillariophyta). Protist, 158:349-364.

Evans, K. M., Wortley, A. H., Simpson, G. E., Chepurnov, V. A. \& Mann, D. G. 2008. A molecular systematic approach to explore diversity within the Sellaphora pupula species complex (Bacillariophyta). J. Phycol., 44:215-231.

Evans, K. M., Chepurnov, V. A., Sluiman, H. J., Thomas, S. J., Spears, B. M. \& Mann, D. G. 2009. Highly differentiated populations of the freshwater diatom Sellaphora capitata suggest limited dispersal and opportunities for allopatric speciation. Protist, 160:386-396 
Finlay, B. J. \& Clarke, K. J. 1999. Ubiquitous dispersal of microbial species. Nature, 400:828.

Finlay, B. J., Monaghan, E. B. \& Maberly, S. C. 2002. Hypothesis: the rate and scale of dispersal of freshwater diatom species is a function of their global abundance. Protist, 153:261-273.

Finlay, B. J., Esteban, G. F. \& Fenchel, T. 2004. Protist diversity is different? Protist, 155:15-22.

Gregory, W. 1857. On new forms of marine Diatomaceae found in the Firth of Clyde and in Loch Fine. Trans. R. Soc. Edinb., 21:473-542.

Guiry, M. D. 2012. How many species of algae are there? J. Phycol., 48:1057-1063.

Huseby, S., Degerlund, M., Zingone, A. \& Hansen, E. 2012. Metabolic fingerprinting reveals differences between northern and southern strains of the cryptic diatom Chaetoceros socialis. Eur. J. Phycol., 47:480-489.

Hustedt, F. 1937-1939. Systematische und ökologische Untersuchungen über die Diatomeen-flora von Java, Bali und Sumatra nach dem Material der Deutschen Limnologischen Sunda-Expedition. Arch. Hydrobiol. (Suppl. 15):393-506, 638790; 16:1-155, 274-394.

Hustedt, F. 1942. Süsswasser-Diatomeen des indomalayischen Archipels und der Hawaii-Inseln. Int. Rev. ges. Hydrobiol. Hydrogr., 42:1-252.

Hutchinson, G. E. 1959. Homage to Santa Rosalia or why are there so many kinds of animals. Am. Nat., 93:145-159.

Kaeriyama, H., Katsuki, E., Otsubo, M., Yamada, M., Ichimi, K., Tada, K. \& Harrison, P. J. 2011. Effects of temperature and irradiance on growth of strains belonging to seven Skeletonema species isolated from Dokai Bay, southern Japan. Eur. J. Phycol., 46:113-124.

Kooistra, W. H. C. F., Sarno, D., Balzano, S., Gu, H., Andersen, R. A. \& Zingone, A. 2008. Global diversity and biogeography of Skeletonema species (Bacillariophyta). Protist, 159:177-193.

Krammer, K. \& Lange-Bertalot, H. 1986-1991. Bacillariophyceae. In: Ettl, H., Gerloff, J., Heynig, H. \& Mollenhauer, D. (ed.), Süßwasserflora von Mitteleuropa, Vol. 2, four parts. Gustav Fischer, Stuttgart.

Kulikovskiy, M. S., Lange-Bertalot, H., Metzeltin, D. \& Witkowski, A. 2012. Lake Baikal: hotspot of endemic diatoms I. In: LangeBertalot, H. (ed.), Iconographia Diatomologica, Vol. 23 Taxonomy - Biogeography - Diversity. A.R.G. Gantner, Ruggell, Liechtenstein. p. 7-607.

Lange-Bertalot, H., Bąk, A. \& Witkowski, A. 2011. Eunotia and some related genera. In: Lange-Bertalot, H. (ed.), Diatoms of Europe. Diatoms of the European Inland Water and Comparable Habitats, Vol. 6. A.R.G. Gantner, Ruggell, Liechtenstein. p. 1-747.

Levkov, Z., Krstic, S., Metzeltin, D. \& Nakov, T. 2007. Diatoms of lakes Prespa and Ohrid. About 500 taxa from ancient lake system. In: Lange-Bertalot, H. (ed.), Iconographia Diatomologica, Vol. 16 Biogeography - Ecology - Taxonomy. A.R.G. Gantner, Ruggell, Liechtenstein. p. 1-611.

Mann, D. G. 1999. The species concept in diatoms. Phycologia, 38:437-495

Mann, D. G. 2010. Discovering diatom species: is a long history of disagreements about species-level taxonomy now at an end? Plant Ecol. Evol., 143:251-264.

Mann, D. G. \& Droop, S. J. M. 1996. Biodiversity, biogeography and conservation of diatoms. Hydrobiologia, 336:19-32.

Mann, D. G. \& Evans, K. M. 2007. Molecular genetics and the neglected art of diatomics. In: Brodie, J. \& Lewis, J. (ed.), Unravelling the Algae - The Past, Present and Future of Algal Systematics. CRC Press, Boca Raton, FL. p. 231-265.
Mann, D. G., McDonald, S. M., Bayer, M. M., Droop, S. J. M., Chepurnov, V. A., Loke, R. E., Ciobanu, A. \& du Buf, J. M. H. 2004. Morphometric analysis, ultrastructure and mating data provide evidence for five new species of Sellaphora (Bacillariophyceae). Phycologia, 43:459-482.

Mann, D. G., Evans, K. M., Chepurnov, V. A. \& Nagai, S. 2009. Morphology and formal description of Sellaphora bisexualis, sp. nov. (Bacillariophyta). Fottea, 9:199-209.

Mann, D. G., Sato, S., Trobajo, R., Vanormelingen, P. \& Souffreau, C. 2010. DNA barcoding for species identification and discovery in diatoms. Cryptog. Algol., 31:557-577.

Mann, D. G., Sato, S., Rovira, L. \& Trobajo, R. 2013. Paedogamy and auxosporulation in Nitzschia sect. Lanceolatae (Bacillariophyta). Phycologia, 52:204-220.

Moschandreou, K. K., Baxevanis, A. D., Katikou, P., Papaefthimiou, D., Nikolaidis, G. \& Abatzopoulos, T. J. 2012. Inter- and intraspecific diversity of Pseudo-nitzschia (Bacillariophyceae) in the northeastern Mediterranean. Eur. J. Phycol., 47:321-339.

Moser, G., Lange-Bertalot, H. \& Metzeltin, D. 1998. Insel der Endemiten. Geobotanisches Phänomen Neukaledonien. In: LangeBertalot, H. \& Kociolek, J. (ed.), Bibliotheca Diatomologica, Vol. 38. J. Cramer, Berlin. p. 1-464.

Park, R. A. 1992. The Ecology of Epipelic Diatoms in Loch Goil. Ph.D. Thesis, University of Edinburgh, UK.

Poulíčková, A., Špačková, J., Kelly, M. G., Duchoslav, M. \& Mann, D. G. 2008. Ecological variation within Sellaphora species complexes (Bacillariophyceae) - specialists or generalists? Hydrobiologia, 614:373-386

Poulíčková, P., Veselá, J., Neustupa, J. \& Škaloud, P. 2010. Pseudocryptic diversity versus cosmopolitanism in diatoms: a case study on Navicula cryptocephala Kütz. (Bacillariophyceae) and morphologically similar taxa. Protist, 161:353-369.

Quijano-Scheggia, S. I., Garcés, E., Lundholm, N., Moestrup, Ø., Andree, K. \& Camp, J. 2009. Morphology, physiology, molecular phylogeny and sexual compatibility of the cryptic Pseudonitzschia delicatissima complex (Bacillariophyta), including the description of $P$. arenysensis sp. nov. Phycologia, 48:492-509.

Shirokawa, Y., Karino, K. \& Mayama, S. 2012. Developmental plasticity and genotype-environment interactions influence valve morphology in the Cyclotella meneghiniana species complex (Bacillariophyceae). Eur. J. Phycol., 47:245-263.

Smith, W. 1853. Synopsis of British Diatomaceae, Vol. 1. John Van Voorst, London.

Souffreau, C., Vanormelingen, P., Sabbe, K. \& Vyverman, W. 2013a. Tolerance of resting cells of freshwater and terrestrial benthic diatoms to experimental desiccation and freezing is habitat-dependent. Phycologia, 52:246-255.

Souffreau, C., Vanormelingen, P., Verleyen, E., Sabbe, K. \& Vyverman, W. 2010. Tolerance of benthic diatoms from temperate aquatic and terrestrial habitats to experimental desiccation and temperature stress. Phycologia, 49:309-324.

Souffreau, C., Vanormelingen, P., Van de Vijver, B., Isheva, T., Verleyen, E., Sabbem, K. \& Vyverman, W. 2013b. Molecular evidence for distinct Antarctic lineages in the cosmopolitan terrestrial diatoms Pinnularia borealis and Hantzschia amphioxys. Protist, 164:101-115.

Stebbins, G. L. 1950. Variation and Evolution in Plants. Columbia University Press, New York.

Theriot, E. 1992. Clusters, species concepts, and morphological evolution of diatoms. Syst. Biol., 41:141-157.

Trainer, V. L., Bates, S. S., Lundholm, N., Thessen, A. E., Cochlan, W. P., Adams, N. G. \& Trick, C. G. 2012. Pseudo-nitzschia physiological ecology, phylogeny, toxicity, monitoring and impacts on ecosystem health. Harmful Algae, 14:271-300 
Trobajo, R., Mann, D. G., Chepurnov, V. A., Clavero, E. \& Cox, E. J. 2006. Auxosporulation and size reduction pattern in Nitzschia fonticola (Bacillariophyta). J. Phycol., 42:1353-1372.

Trobajo, R., Clavero, E., Chepurnov, V. A., Sabbe, K., Mann, D. G., Ishihara, S. \& Cox, E. J. 2009. Morphological, genetic, and mating diversity within the widespread bioindicator Nitzschia palea (Bacillariophyceae). Phycologia, 48:443-459.

Trobajo, R., Mann, D. G., Clavero, E., Evans, K. M., Vanormelingen, P. \& McGregor, R. C. 2010. The use of partial cox1, rbcL and LSU rDNA sequences for phylogenetics and species identification within the Nitzschia palea complex (Bacillariophyceae). Eur. J. Phycol., 45:413-425.

Trobajo, R., Rovira, L., Mann, D. G. \& Cox, E. J. 2011. Effects of salinity on growth and on valve morphology of five estuarine diatoms. Phycol. Res., 59:83-90.

Trobajo, R., Rovira, L., Ector, L., Wetzel, C. E., Kelly, M. \& Mann, D. G. 2013. Morphology and identity of some ecologically important small Nitzschia species. Diatom Res., 28:37-59.

Van de Vijver, B., Kelly, M., Blanco, S., Jarlman, A. \& Ector, L. 2008. The unmasking of a sub-Antarctic endemic: Psammothidium abundans (Manguin) Bukhtiyarova et Round in European rivers. Diatom Res., 23:233-242.

Vanelslander, B., Creach, V., Vanormelingen, P., Ernst, A., Chepurnov, V. A., Sahan, E., Muyzer, G., Stal, L. J., Vyverman, W. \& Sabbe, K. 2009. Ecological differentiation between sympatric pseudocryptic species in the estuarine benthic diatom Navicula phyllepta (Bacillariophyceae). J. Phycol., 45:1278-1289.

VanLandingham, S. L. 1967-1979. Catalogue of the fossil and recent genera and species of diatoms and their synonyms. J. Cramer, Vaduz.

Vanormelingen, P., Chepurnov, V. A., Mann, D. G., Cousin, S. \& Vyverman, W. 2007. Congruence of morphological, reproductive and ITS rDNA sequence data in some Australasian Eunotia bilunaris (Bacillariophyta). Eur. J. Phycol., 48:61-79.

Vanormelingen, P., Evans, K. M., Chepurnov, V. A., Vyverman, W. \& Mann, D. G. in press. Molecular species discovery in the diatom Sellaphora and its congruence with mating trials. Fottea, 13.

Vanormelingen, P., Verleyen, E. \& Vyverman, W. 2008a. The diversity and distribution of diatoms: from cosmopolitanism to narrow endemism. Biodivers. Conserv., 17:393-405.

Vanormelingen, P., Chepurnov, V. A., Mann, D. G., Sabbe, K. \& Vyverman, W. 2008b. Genetic divergence and reproductive barriers among morphologically heterogeneous sympatric clones of Eunotia bilunaris sensu lato (Bacillariophyta). Protist, 159:73-90.

Vanormelingen, P., Vanelslander, B., Sato, S., Gillard, J., Trobajo, R., Sabbe, K. \& Vyverman, W. 2013. Heterothallic sexual reproduction in the model diatom Cylindrotheca. Eur. J. Phycol., 48:93-105.

Veselá, J., Urbánková, Černa, K. \& Neustupa, J. 2012. Ecological variation within traditional diatom morphospecies: diversity of Frustulia rhomboides sensu lato (Bacillariophyceae) in European freshwater habitats. Phycologia, 51:552-561.

Vyverman, W., Verleyen, E., Sabbe, K., Vanhoutte, K., Sterken, M., Hodgson, D. A., Mann, D. G., Juggins, S., Van de Vijver, B., Jones, V., Flower, R., Roberts, D., Chepurnov, V. A., Kilroy, C., Vanormelingen, P. \& De Wever, A. 2007. Historical processes constrain patterns in global diatom diversity. Ecology, 88:1924-1931.

Werner, D. (ed.) 1977. The Biology of Diatoms. Blackwell Scientific Publications, Oxford.

\section{SUPPORTING INFORMATION}

Additional Supporting Information may be found in the online version of this article:

Appendix S1. Analysis of selected genera and species to estimate the extent to which current knowledge underestimates the total species diversity of diatoms. 